\title{
Overwintering form of Erysiphe necator, the causal agent of grapevine powdery mildew in southern Syria
}

\author{
Nujoud Alimad ${ }^{1}$, Walid Naffaa ${ }^{2 *}$, Fawaz Azmeh ${ }^{3}$ \\ ${ }^{1}$ Second Faculty of Agriculture, Damascus University, Sweida, Syria \\ 2 Department of Plant Protection, Faculty of Agriculture, Damascus University, 30621 Damascus, Syria \\ ${ }^{3}$ National Commission for Biotechnology, 301902, Damascus, Syria
}

Vol. 57, No. 2: 129-135, 2017

DOI: 10.1515/jppr-2017-0017

Received: September 23, 2016 Accepted: May 17, 2017

${ }^{*}$ Corresponding address: ray-dya@scs-net.org; walid1851966@yahoo.com

\begin{abstract}
The main aims of this study were to determine the overwintering form and the primary inoculum of Erysiphe necator, the causal agent of grapevine powdery mildew in southern Syria. Eleven vineyards located at five different geographical sites were visited every week from March to November in 2014 and 2015. The results of field and histopathological studies showed that $E$. necator survived as mycelium in dormant grapevine buds during the winter season. The first flag shoots were observed shortly after bud break in spring. The number of flag shoots varied greatly according to vineyards, cultivars and years, being present on 27.4 to $61.9 \%$ of the grapevines in 2014 , and on 5.2 to $40 \%$ of the grapevines in 2015 . The percentage of flag shoots on the same grapevine also varied according to the year, cultivar and location. It was between 4.3 to $9.4 \%$ in 2014 , and 2.1 to $3.6 \%$ in 2015 . The disease was observed only on Balady and Black cultivars. Conidia were released from the second week of May to early September. The first conidia were trapped around mid-May, and the first secondary symptoms were observed on leaves from mid-May to early June according to the site. Chasmothecia were observed on leaves in $45.5 \%$ of the studied vineyards. The first observation of chasmothecia on leaves was in July, and their numbers varied greatly between vineyards and years. Chasmothecia were not detected on bark, nor were ascospores trapped at the beginning of the season. These results confirmed that the ascospores did not have any role in the initiation of spring infection. To the best of our knowledge, this is the first report of the overwintering form of E. necator in Syria.
\end{abstract}

Key words: Erysiphe necator, grapevine, overwintering, powdery mildew, Syria

\section{Introduction}

Grapevine powdery mildew, caused by Erysiphe necator (syn. Uncinula necator) is the most widespread and destructive disease of grapevines (Halleen and $\mathrm{Holz}$ 2001; Khiavi et al. 2009). Powdery mildew may be observed on all the green parts of the grapevine: leaves, branches, inflorescences, pedicels and berries (Bulit and Lafon 1978). Erysiphe necator produces sexual fruiting bodies (chasmothecia) only on the surface of heavily diseased grapevine tissue (Hill et al. 1995; Fathi and Karbalaei 2012). Chasmothecia are produced primarily on leaves, but also on shoots, bunches, rachises and berries (Pearson and Gadoury 1987). Many aspects of the epidemiology of grapevine powdery mildew were reviewed by Gadoury et al. (2011). There are two principal sources of primary inoculum: hyphae inside dormant buds and chasmothecia on the surface of the grapevine. In areas with relatively mild winters, the fungus remains dormant as mycelium in buds until the following spring, when lateral infected buds give rise to flag shoots covered with white mycelium and abundant sporulation (Sall and Wyrsinski 1982; Pearson and Gärtel 1985). Conidia produced on these flag shoots infect neighboring shoots and grapevines (Pearson and Gadoury 1987). Flag shoots are most easily detected 3-8 weeks after bud break, and they appear to be most prevalent on grapevines of more susceptible 
varieties that were heavily diseased early in the previous season. Most flag shoots also appear on the same grapevines year after year (Bleyer et al. 1998). The incidence of flag shoots in vineyards is usually very low, ranging from 0 to $0.2 \%$ (Emmett et al. 1990).

In most viticultural areas, chasmothecia that lodge on the grapevine bark are the main source of primary inoculum of powdery mildew, and they provide an additional source of primary inoculum when the flag shoots are common (Hill et al. 1995). Chasmothecia can form on all infected tissues from early summer to autumn. Environmental factors such as temperature, day length, humidity, leaf age and host resistance do not affect chasmothecium initiation and, once initiated, only temperature and host resistance affect their growth (Pearson and Gadoury 1987). However, the density of ascospores in the air is correlated with weather factors especially rainfall (Holb and Füzi 2016). Initial infections due to ascospores are most often found on the undersides of the first-formed leaves of shoots growing in close proximity to the bark of the grapevine. Rainfall is therefore a critical event in the release of ascospores and the initiation of powdery mildew epidemics in areas where chasmothecia are sources of primary inoculum. Ascospores germinate in water as well as at relative humidity as low as 54\% (Pearson 1990).

In southern Syria, powdery mildew is one of the most important grapevine fungal diseases, and it causes heavy yield losses because the weather conditions are favorable for its development. In this area, an intense application of fungicides from bud break to the end of the season is necessary to protect grapevines from the disease. No studies have been previously conducted on the biology of E. necator in Syria, and the sources of primary inoculum are still not clear. So, the objectives of this study were to determine the biology and the overwintering form of E. necator in vineyards of southern Syria.

\section{Materials and Methods}

\section{Observations on flag shoots}

In 2014 and 2015, 11 vineyards located at five different geographical sites in Sweida in the south of Syria, where many local grape cultivars are grown (Tab. 1), were visited every week from March to November of each year. The presence and distribution of flag shoots were surveyed at the beginning of each growing season (April-May). The date of the appearance of the first powdery mildew symptoms was recorded, and it was determined whether they originated from an infection by sexually produced ascospores or were produced by infection from in-bud overwintered mycelium. Then, the development of powdery mildew was continuously observed.

\section{Examination of dormant twigs for survival of fungal mycelium}

During March, just before bud break, grapevine branches showing reddish-brown to black discoloration on

Table 1. Vineyard areas, grapevine cultivars and regions where the study was conducted

\begin{tabular}{|c|c|c|c|c|c|}
\hline $\begin{array}{l}\text { Vineyard } \\
\text { No. }\end{array}$ & Location & Cultivar & Training system & $\begin{array}{l}\text { Observed area } \\
\qquad\left[\mathrm{m}^{2}\right]\end{array}$ & $\begin{array}{l}\text { Altitude } \\
\text { [m] }\end{array}$ \\
\hline 1 & Kanawat $1^{\text {st }}$ & Balady & Earth-trellised "Jui" system & 4,000 & 1,270 \\
\hline 2 & Kanawat $1^{\text {st }}$ & Black & Earth-trellised "Jui" system & 2,000 & 1,270 \\
\hline 3 & Kanawat $2^{\text {nd }}$ & Balady & Arbour vineyard & 2,000 & 1,250 \\
\hline 4 & Kanawat $2^{\text {nd }}$ & Black & Arbour vineyard & 1,000 & 1,250 \\
\hline 5 & Kanawat $2^{\text {nd }}$ & Helwani & Arbour vineyard & 1,000 & 1,250 \\
\hline 6 & Kanawat $2^{\text {nd }}$ & Salty & Arbour vineyard & 400 & 1,250 \\
\hline 7 & $\begin{array}{c}\text { Daher Aljabel } \\
\text { (Research Center)/1 }\end{array}$ & Black & Lateral cordon & 5,000 & 1,500 \\
\hline 8 & $\begin{array}{c}\text { Daher Aljabel } \\
\text { (Research Center)/2 }\end{array}$ & Balady & Head-trained vine & 5,000 & 1,500 \\
\hline 9 & $\begin{array}{c}\text { Daher Aljabel } \\
\text { (Research Center)/3 }\end{array}$ & Black & Earth-trellised "Jui" system & 100 & 1,500 \\
\hline 10 & Daher Aljabel (Albassa) & Salty & Earth-trellised "Jui" system & 300 & 1,450 \\
\hline 11 & Salkhad & Balady & Arbour vineyard & 200 & 1,350 \\
\hline
\end{tabular}


the surface were collected from 20 Balady and Black grapevine cultivars from different experimental sites (Kanawat $1^{\text {st }}$, Kanawat $2^{\text {nd }}$ and Daher Aljabel/3), and taken to the laboratory for further study. Buds were removed, and thin profiles were prepared by fixing, staining, molding in paraffin and microtome profiling, according to Gee et al. (2000). Profiles were then examined under a light microscope for the detection of E. necator mycelium.

\section{Conidia and ascospores release}

In this experiment, for determination of primary and secondary infection sources, in each vineyard, $125 \times$ $\times 10 \times 2.5 \mathrm{~cm}$ wooden stands were built with platforms 25, 50, 75 and $100 \mathrm{~cm}$ above the soil surface. Each platform was $75 \mathrm{~mm}$ height by $2.5 \mathrm{~mm}$ thick. At the beginning of March, three stands were placed between the rows in each of four selected locations (Kanawat $1^{\text {st }}$, Daher Aljabel/1, Daher Aljabel/2 and Daher Aljabel/ Albassah). Then, four microscopic slides covered with Vaseline were vertically placed on each of the four platforms of all the stands for spore trapping. Slides were taken to the laboratory every 7 days. Each week 192 slides were stained with cotton blue-lacto-phenol solution, and the numbers of trapped spores were morphologically identified and recorded using a light microscope (Holb and Füzi 2016).

\section{The occurrence of chasmothecia}

The occurrence of chasmothecia and their formation development were assessed through observation of leaves in eleven vineyards. One hundred leaves showing powdery mildew symptoms were collected every 7-10 days from June until leaf fall. In spring, just before bud break, 50 samples of branches were collected, brought to the laboratory and examined for chasmothecia formation on the bark (Cortesi et al. 1995). Leaves and branches were examined with a stereo binocular for observation of the chasmothecia, and the number of chasmothecia was estimated on the upper and lower surfaces of the leaves. Samples of $30 \mathrm{~g}$ of bark were placed in 21 Erlenmeyer flasks containing 1.51 of water. The flasks were shaken vigorously by hand for $3 \mathrm{~min}$ and the suspension was filtered through 120 -mesh and 150-mesh Cobb sieves. The contents of the 150-mesh sieve were recovered in $25 \mathrm{ml}$ of water, and the suspension was examined under a light microscope (Hajjeh et al. 2008).

\section{Statistical analysis}

One-way analysis of variance was carried out using SPSS15 statistical program at $\mathrm{p} \leq 0.05$ to compare differences in the number of conidia captured during the grapevine growth season at each of the four platforms of the wooden traps.

\section{Results and Discussion}

\section{Flag shoots}

In spring, the first flag shoots were observed and recognized shortly after the bud break. Shoots, covered with white mycelium and abundant sporulation, were short (5-15 cm long) with wrinkled and deformed leaves. The uninfected shoots were from 30 to $50 \mathrm{~cm}$ long. Flag shoots were found in 1, 2, 3, 4, 9 and 11 vineyards during the two years of observations (Table 2). The first flag shoots, $8-15 \mathrm{~cm}$ long were observed in the Kanawat and Salkad vineyards at the end of April, and in early May in Daher Aljabel/3 in 2014. Whereas, they were observed later in 2015, and weren't noticed until the end of May at the Kanawat sites with flag shoots 5-9 cm long, and in early June at the $3^{\text {rd }}$ Daher Aljabel site.

Table 2. Vineyard number, locations, cultivars, percentage of powdery mildew infected vines, percentage of flag shoots on the same vine and the date of first observation of flag shoots

\begin{tabular}{|c|c|c|c|c|c|c|c|c|}
\hline \multirow{2}{*}{$\begin{array}{l}\text { Vineyard } \\
\text { No. }\end{array}$} & \multirow{2}{*}{ Location } & \multirow{2}{*}{ Cultivar } & \multicolumn{2}{|c|}{$\begin{array}{l}\text { Percentage of vines } \\
\text { showing flag shoots }\end{array}$} & \multicolumn{2}{|c|}{$\begin{array}{c}\text { Percentage of flag } \\
\text { shoots on the same vine }\end{array}$} & \multicolumn{2}{|c|}{$\begin{array}{c}\text { First observation } \\
\text { of flag shoots }\end{array}$} \\
\hline & & & 2014 & 2015 & 2014 & 2015 & 2014 & 2015 \\
\hline 1 & Kanawat $1^{\text {st }}$ & Balady & 42.1 & 23.07 & 7.7 & 3.6 & $22 / 4$ & $21 / 5$ \\
\hline 2 & Kanawat $1^{\text {st }}$ & Black & 61.9 & 40.00 & 6.1 & 2.1 & $22 / 4$ & $21 / 5$ \\
\hline 3 & Kanawat $2^{\text {nd }}$ & Balady & 29.9 & 12.00 & 5.9 & 3.4 & $27 / 4$ & $28 / 5$ \\
\hline 4 & Kanawat $2^{\text {nd }}$ & Black & 30.0 & 8.33 & 7.6 & 3.1 & $27 / 4$ & $28 / 5$ \\
\hline 9 & $\begin{array}{c}\text { Daher Aljabel } \\
\text { (Research Center)/3 }\end{array}$ & Black & 32.5 & 5.20 & 9.4 & 2.9 & $6 / 5$ & $2 / 6$ \\
\hline 11 & Salkhad & Balady & 27.4 & 12.90 & 4.3 & 2.2 & $27 / 4$ & $7 / 5$ \\
\hline
\end{tabular}


The number of flag shoots varied greatly from vineyard to vineyard, cultivar to cultivar and year to year, being present on 27.4 to $61.9 \%$ of the grapevines in 2014 , and on 5.2 to $40 \%$ of the grapevines in 2015 . Flag shoots were absent in vineyards No. 7 and 8, although powdery mildew symptoms were observed later as small colonies on leaves and berries. No flag shoots were observed in vineyards No. 5, 6 and 10 during the two years, and Helwani and Salty cultivars didn 't show any symptoms of powdery mildew infection. The percentage of flag shoots on the same grapevine also varied according to the year, the cultivar and the location. It was between 4.3 to $9.4 \%$ in 2014 , and 2.1 to $3.6 \%$ in 2015. They were observed on Balady and Black cultivars, but they were not observed on Helwani and Salty cultivars. Flag shoots were also seen more frequently in 2014.

These results were also confirmed by cytological study, which detected dormant mycelium in $12.7 \%$ of the observed grapevine buds.

\section{Conidia release}

The first conidia were trapped around mid-May in Kanawat $1^{\text {st }}$ (Fig. 1) and at the end of May in Daher Aljabel (Fig. 2). The number of conidia increased with time until mid-June, then it began to decrease gradually. It is clear that the largest number of conidia was trapped at a height of $25 \mathrm{~cm}$ in the wooden trap, while a relatively small number of conidia was trapped at a height of $100 \mathrm{~cm}$ in Kanawat's $1^{\text {st }}$ location, where the grapevines are planted using the earth-trellised "Jui" system (Fig. 1). While the number of conidia trapped in the Daher Eljabel location was relatively low, it also increased until the end of June. More conidia were captured at the higher platforms of the wooden traps (50 and $75 \mathrm{~cm}$ ). The vines at this site are planted using a lateral cordon training system.

\section{Chasmothecia formation}

Leaves were examined for chasmothecia formation from July to November, 2014-2015. They were detected in 5 out of 11 vineyards during the two years of the survey. The number of chasmothecia formed on the leaves at the end of the season was estimated only in vineyard No. 1 (Kanawat $1^{\text {st }}$ ) in 2014-2015, and vineyard No. 4 (Kanawat $2^{\text {nd }}$ ) in 2015. The results showed that the number of chasmothecia varied between vineyards and years. In 2014, their numbers ranged between 27 (vineyard No. 4) to 252 (vineyard No. 1) on 100 leaves (Fig. 3). The first detection of chasmothecia on leaves was at the beginning of July in two of the surveyed vineyards and during the two years of the survey, but the number of chasmothecia also varied greatly between years in the same vineyard. In Kanawat 1 in November 2014 there were 367 while in November 2015 there were about 198. Figure 4 shows the mean number of chasmothecia seen in each month.

At the time of bud break, in March-April 2014 and 2015 , chasmothecia were not found on grapevine bark. No ascospores were trapped in the wooden traps at the beginning of the season.

The results of this study showed that the causal agent of grapevine powdery mildew (E. necator) overwinters as mycelium in dormant buds of the grapevines, where it stays in a dormant state until the following season. Although chasmothecia have been observed on infected leaves at the end of the grapevine

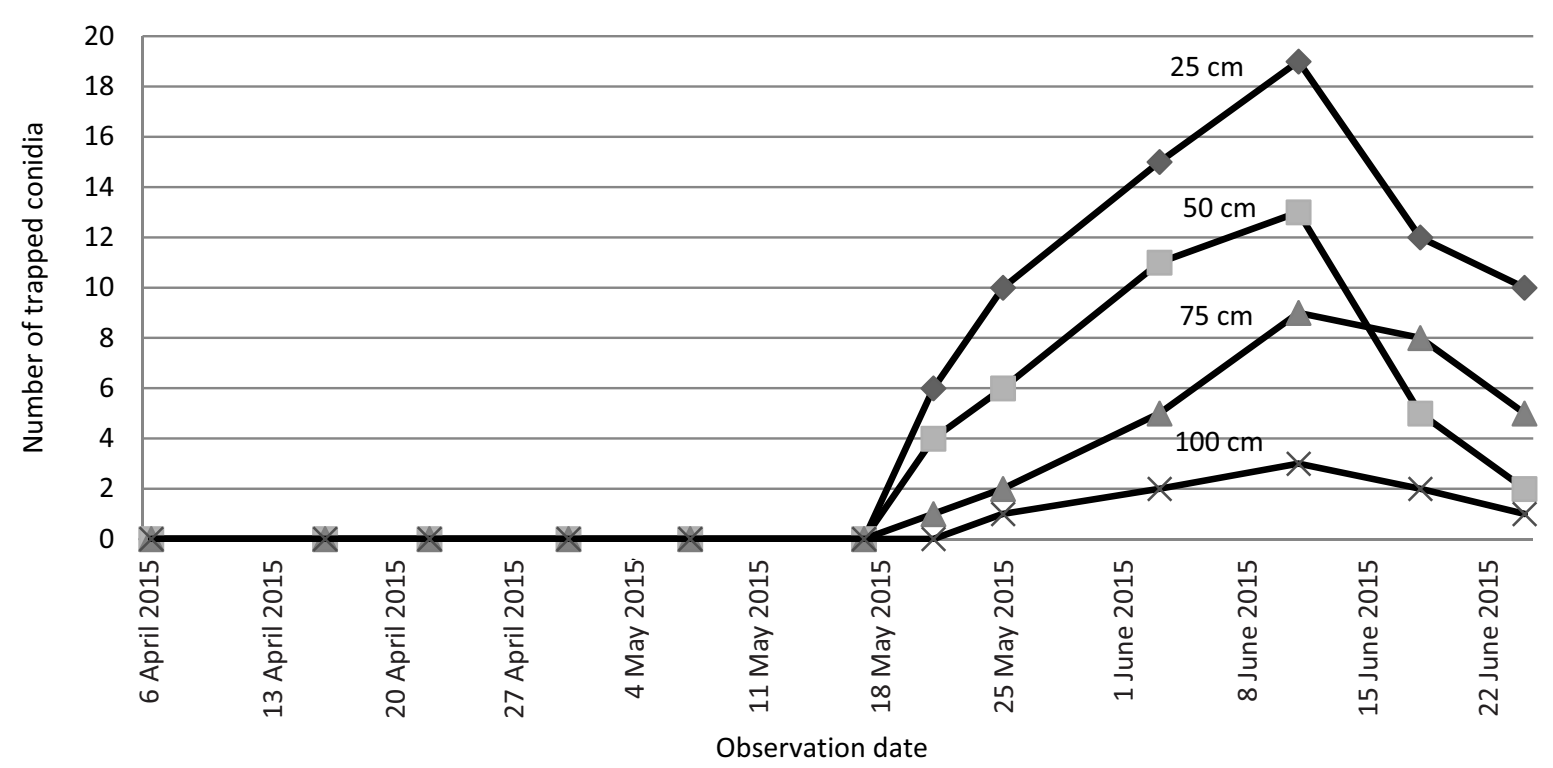

Fig. 1. Number of conidia captured during the grapevine growth season on $4 \mathrm{~cm}^{2}$ of slide at each of four levels of wooden traps at Kanawat $1^{\text {st }}$ site 


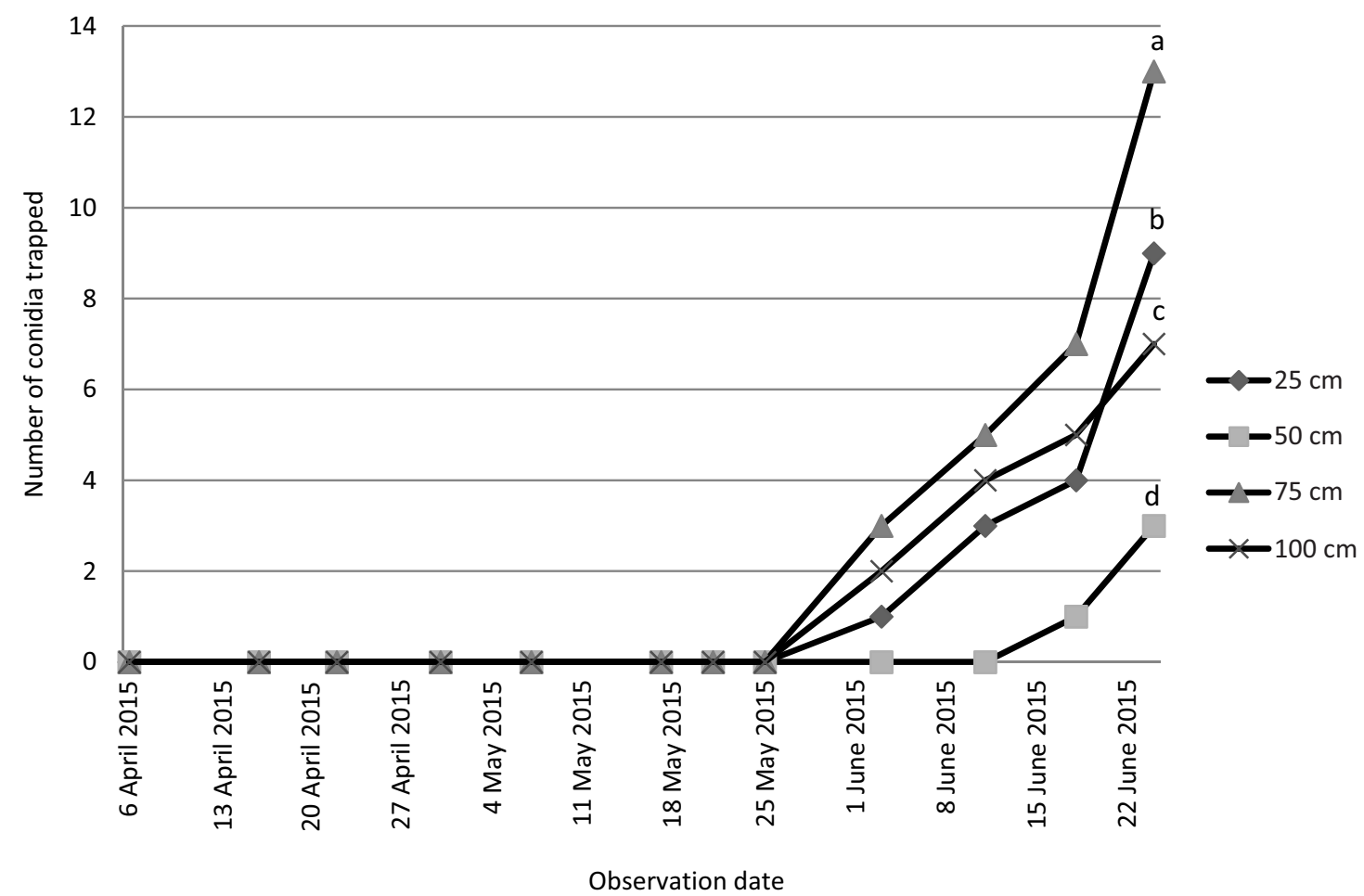

Fig. 2. Number of conidia captured during the grapevine growth season on $4 \mathrm{~cm}^{2}$ of slide at each of four levels of wooden traps at Daher Eljabel/1 site. Data with different letters are significantly different $(p \leq 0.05)$

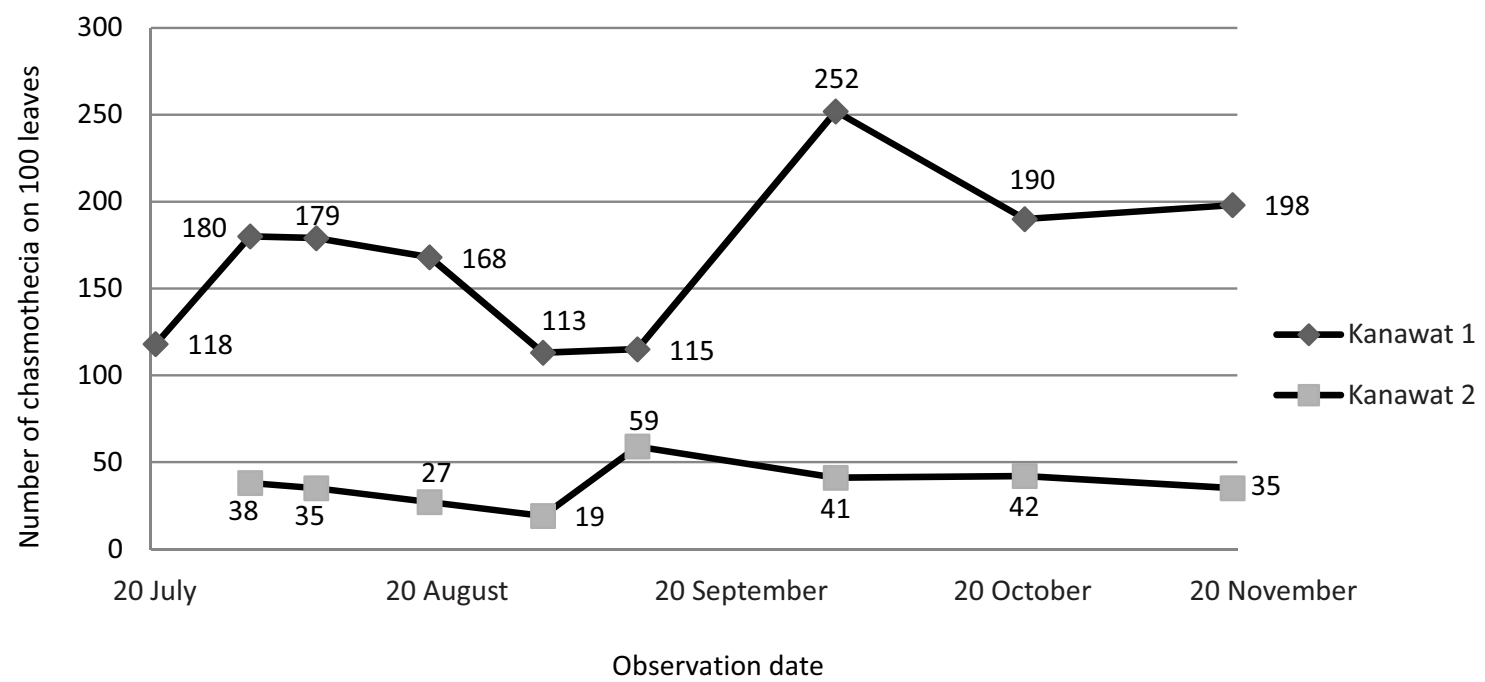

Fig. 3. The number of chasmothecia observed on 100 leaves in vineyards No. 1 (Kanawat 1) and No. 2 (Kanawat 2) from July to November 2015

growing season, it seems that the ascospores do not have any role in the initiation of the disease in spring. The number of chasmothecia formed on leaves was very different between vineyards and years, which agrees with Hajjeh et al. (2008). No ascospores were found on the bark at the beginning of spring, although they were observed on the leaves in autumn. Holb and Füzi (2016) showed that the releasing of ascospores was significantly correlated with three weather factors (rainfall, relative humidity and temperature). In fact, the efficiency of transferring the chasmothecia from infected leaves to the bark is determined by rain. Late summer and autumn rains wash them onto the bark of the grapevine where they overwinter (Cortesi et al. 1995, 1997). Insufficient autumn rains may affect the transfer of chasmothecia from the leaves to the bark, resulting in a residue of viable chasmothecia that survive on fallen leaves (Cortesi et al.1997; Jailloux et al. 1999). So, the absence of chasmothecia on grapevine bark may be explained by the lack of rain in southern Syria, especially during recent years, in autumn before the leaves fall. These results are also in line with Hejjeh 


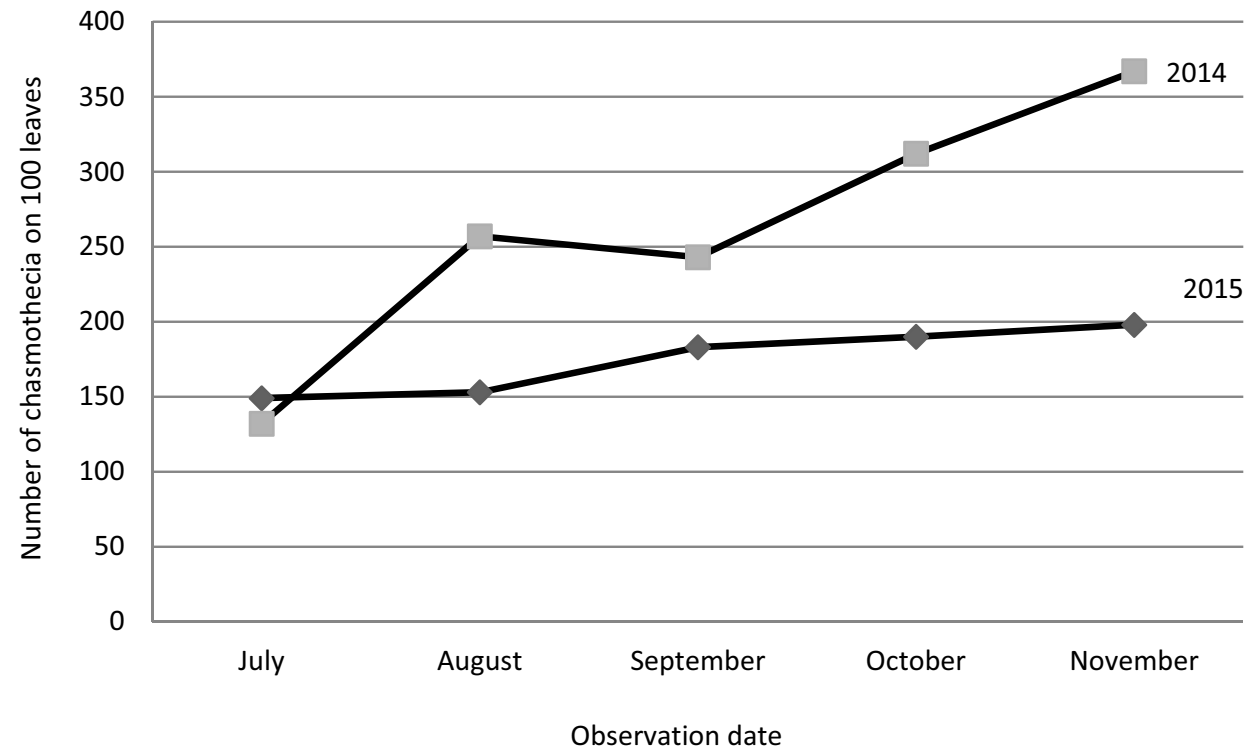

Fig. 4. The number of chasmothecia observed on 100 leaves in vineyard No. 1 (Kanawat 1) from July to November of 2014 and 2015. The number of chasmothecia was calculated as the average of observations made in each month

et al. (2008) who did not find any chasmothecia on the bark in southern Italy. Halleen and Holze (2000) detected chasmothecia on leaves, but they were dispersed in very small numbers from leaves to the bark of grapevines in the Stellenbosch area. The flag shoots and the number of chasmothecia on leaves were found more frequently in earth-trellised "Jui" vineyard systems than in arbor vineyard training systems. These results are in contrast to those of Austin and Wilcox (2011) who showed that there was no effect of training systems on disease development.

According to our results, all recorded infections at our sites were as shoots entirely covered with mycelium produced by asexual inoculum. In fact, the dominance of either sexual or asexual overwintering forms of $E$. necator have been investigated in several grapevine growing regions of the world (Steinkellner 1998; Grove et al. 1999; Halleen and Holz 2000; Grove 2004; Miladinovic et al. 2007). These results are in line with many previous studies (Gemmrich and Seidel 1996; Halleen and Holz 2001; Hajjeh et al. 2008). In contrast, several other studies showed that the ascospores released from the chasmothecia had an important role in the initiation of spring infection (Gadoury et al. 1994; Magarey et al. 2000; Moyer et al. 2008; Taksonyi et al. 2010). In New York (Pearson and Gadoury 1987) and some Italian vineyards (Cortesi et al. 1997), chasmothecia are the only source of primary inoculum. But, in France (Bulit and Lafon 1978), California (Gubler et al. 1988), Peru (Pearson and Gadoury 1992), Australia (Magarey et al. 1993), Germany (Hill et al. 1995), Iran (Banihashemi and Parvin 1995), Russia and other Italian vineyards (Cortesi et al. 1997) chasmothecia are not the main source of primary inoculum.
The flag shoots carry abundant conidia that cause secondary infections to neighboring leaves and grapevines (Hajjeh et al. 2008), so our results agree with previous studies (Bulit and Lafon 1978; Person and Gadoury 1992; Magary et al. 1993; Banihashemi and Parvin 1995; Hill et al. 1995; Cortesi et al. 1997; Peros et al. 2005; Fathi and Karbalaei 2012). In Daher Eljabel site 3, neither shoots nor powdery mildew colonies originating from infection by ascospores were found. It seems that the disease symptoms always appeared late, mid to early June, and must have been the result of conidial infection. Flag shoots were also found more frequently in 2014. The vineyards were affected by a freeze in early spring 2015 when the temperature reached $-16^{\circ} \mathrm{C}$ and killed most of the branches. This explanation was confirmed by the fact that most flag shoots were observed on two year old branches in 2014, while they were on old wood in 2015.

The results of this study are the first report about the overwintering form and the primary inoculum of grapevine powdery mildew in southern Syria.

\section{References}

Austin C.N., Wilcox W.F. 2011. Effects of fruit-zone leaf removal, training systems, and irrigation on the development of grapevine powdery mildew. American Journal of Enology and Viticulture 62 (2): 193-198. DOI: 10.5344/ ajev.2010.10084

Banihashemi Z., Parvin S. 1995. The occurrence of ascigenous stage of Uncinula necator var. necator in fars. Iranian Journal Plant Pathology 31: 1-4.

B1eyer G., Huber B., Kassemeyer H.H. 1998. Investigations on relationships of treatments before bloom against Uncinula necator, appearance of flag shoots and epidemics on leaves 
and grapes in 1993-1997. SARDI Research Report Series No. 22: 54.

Bulit J., Lafon R. 1978. Powdery mildew of the vine. p. 525-548. In: "The Powdery Mildews" (D.M. Spencer, ed.). Academic Press, New York.

Cortesi P., Bisiach M., Ricciolini M., Gadoury D.M. 1997. Cleistothecia of Uncinula necator - an additional source of inoculum in Italian vineyards. Plant Disease 81 (8): 922-926. DOI: 10.1094/PDIS.1997.81.8.922

Cortesi P., Gadoury D.M., Seem R.C., Pearson R.C. 1995. Distribution and retention of cleistothecia of Uncinula necator on the bark of grapevines. Plant Disease 79: 15-19.

Emmett R.W., Wicks T.J., Magarey P.A., Madge D.G. 1990. Recent developments in grapevine powdery mildew management. Australian and New Zealand Wine Industry Journal 5 (3): 213-217.

Fathi H., Karbalaei H. 2012. Study of biology and epidemiology of Uncinula necator caused powdery mildew disease. Technical Journal of Engineering and Applied Sciences 2 (3): 56-61.

Gadoury D.M., Cadle-Davidson L., Wilcox W.F., Dry I.B., Seem R.C., Milgroom M.G. 2011. Grapevine powdery mildew (Erysiphe necator): A fascinating system for the study of the biology, ecology and epidemiology of an obligate biotroph. Molecular Plant Pathology 13 (1): 1-16. DOI: 10.1111/j.1364-3703.2011.00728.x.

Gadoury D.M., Pearson R.C., Riegel D.G., Seem R.C., Becker E.M., Psheidt J.W. 1994. Reduction of powdery mildew and other diseases by over-the-trellis applications of lime sulfur to dormant grapevines. Plant Disease 78 (1): 83-87.

Gadoury D.M., Seem R.C., Pearson R.C., Wilcox W.F. 2001. Effects of powdery mildew on vine growth, yield, and quality of concord grapes. Plant Disease 85 (2): 137-140. DOI: 10.1094/PDIS.2001.85.2.137

Gee L.M., Stummer B.E., Gadoury D.M., Biggins L.T., Scott E.S. 2000. Maturation of chasmothecia of Uncinula necator (powdery mildew) and release of ascospores in southern Australia. Australian Journal of Grape and Wine Research 6 (1): 13-20. DOI: 10.1111/j.1755-0238.2000.tb00157.x

Gemmrich A.R., Seidel M. 1996. Immunodetection of overwintering Oidium mycelium in bud scales of Vitis vinifera. Vitis 35 (1): 63-64.

Grove G.G. 2004. Perennation of Uncinula necator in vineyards of Eastern Washington. Plant Disease 88 (3): 242-247. DOI: 10.1094/PDIS.2004.88.3.242

Grove G., Davis G., Duplaga B., Boal R. 1999. Powdery mildew of grape: Perennation of Uncinula necator in Eastern Washington. Phytopathology 89: S30.

Gubler W.D., Fogle D.G., Chellemi D.O. 1988. Viability and pathogenicity of Uncinula necator ascospores in California. Phytopathology 78: 1572.

Hajjeh H., Miazzi M., Faretra F. 2008. Overwintering of Erysiphe necator Schw. in Southern Italy. Journal of Plant Pathology 90 (2): 323-330.

Halleen P., Holz G. 2000. Chasmothecia and flag shoots: sources of primary inoculum for grape powdery mildew in the Western Cape province, South Africa. South African Journal of Enology and Viticulture 21: 66-70.

Halleen F., Holz G. 2001. An overview of the biology, epidemiology and control of Uncinula necator (powdery mildew) on grapevine, with reference to South Africa. South African Journal of Enology and Viticulture 22: 111-121.
Hill G.K., Baumberger I., Spies S. 1995. Studies on the occurrence of the chasmothecia of Uncinula necator (Schw.) Burr. in two vine growing areas of Germany. Viticulture and Enology Sciences 50: 3-8.

Holb I.J., Füzi I. 2016. Monitoring of ascospore density of Erysiphe necator in the air in relation to weather factors and powdery mildew development. European Journal of Plant Pathology 144 (4): 751-762. DOI: 10.1007/s10658-015$-0823-4$

Jailloux F., Willocquet L., Chapuis L., Froidefond G. 1999. Effect of weather factors on the release of ascospores of Uncinula necator, the cause of grape powdery mildew, in the Bordeaux region. Canadian Journal of Botany 77 (7): 1044-1051. DOI: $10.1139 / \mathrm{b} 99-118$

Khiavi H.K., Shikhlinski H., Ahari A.B., Heydari A. 2009. Evaluation of different grape varieties for resistance to powdery mildew caused by Uncinula necator. Journal of Plant Protection Research 49 (4): 434-439. DOI: 10.5897/ AJAR12.1056

Magarey R.D., Wachtel M.F., Masters J., Wilkins B.J. 1993. Chasmothecia as primary inoculum sources of grapevine powdery mildew (Uncinula necator) in Australia. Australian and New Zealand Wine Industry Journal 8: 239-241.

Magarey P.A., Magarey R.D., Emmett R.W. 2000. Principles for managing the foliage diseases of grapevine with low input of pesticides. IFOAM 2000 - the world grows organic. p. 140148. In: Proceedings of the 6th International Congress on Organic Viticulture, Convention Center, Basel, Switzerland, 25-26 August 2000

Miladinovic Z., Vuksa P., Miletic N. 2007. Uncinula necator (Schw.) Burr: source of inoculum in Podgorica vineyards. Pesticidi i Fitomedicina 22: 131-135.

Moyer M.M., Gadoury D.M., Wilcox W.F., Seem R.C. 2008. Seasonal release of ascospores by Erysiphe necator. Phytopathology 98: S109.

Pearson R.C. 1990. Current research on grape fungal diseases and their control in New York. Australian and New Zealand Wine Industry Journal 5: 206-209.

Pearson R.C., Gärtel W. 1985. Occurrence of hyphae of Uncinula necator in buds of grapevine. Plant Disease 69: 149-151.

Pearson R.C., Gadoury D.M. 1987. Chasmothecia, the source of primary inoculum for grape powdery mildew in New York. Phytopathology 77: 1509-1514.

Pearson R.C., Gadoury D.M. 1992. Grape powdery mildew. p. 129-146. In: "Plant Diseases of International Importance" Vol. III. Diseases of Fruit Crops (J. Kumar, H.S. Chaube, U.S. Singh, A.N. Mukhopadhyay, eds.). Englewood Cliffs, NJ, Prentice Hall.

Péros G.P., Troulet C., Guerriero M., Romiti C.M., Notteghem J.L. 2005. Genetic variation and population structure of the grape powdery mildew fungus, Erysiphe necator, in southern France. European Journal of Plant Pathology 113 (4): 407-416. DOI: $10.1007 /$ s10658-005-4563-8

Sall M.A., Wrysinski J. 1982. Perennation of powdery mildew in buds of grapevines. Plant Disease 66 (8): 678-679.

Steinkellner S. 1998. Overwintering of Uncinula necator in Austrian vineyards. Vitis 37: 193-194.

Taksonyi P., Tarczal E., Maráczi K., Holb I., Kocsis L. 2010. Powdery mildew infection dependent on weather factors in vineyards near Keszthely in 2008. International Journal of Horticultural Science 16 (2): 55-59. 